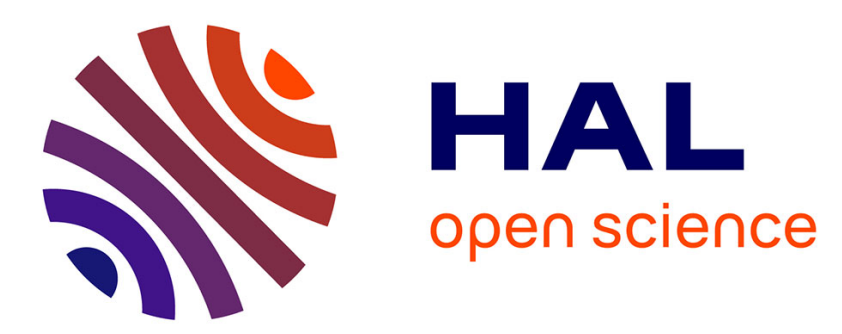

\title{
Steam pretreatment of dry and ensiled industrial hemp for ethanol production
}

Bálint Sipos, Emma Kreuger, Sven-Erik Svensson, Kati Réczey, Lovisa Björnsson, Guido Zacchi

\section{- To cite this version:}

Bálint Sipos, Emma Kreuger, Sven-Erik Svensson, Kati Réczey, Lovisa Björnsson, et al.. Steam pretreatment of dry and ensiled industrial hemp for ethanol production. Biomass and Bioenergy, 2010, 34 (12), pp.1721. 10.1016/j.biombioe.2010.07.003 . hal-00748065

\section{HAL Id: hal-00748065 https://hal.science/hal-00748065}

Submitted on 4 Nov 2012

HAL is a multi-disciplinary open access archive for the deposit and dissemination of scientific research documents, whether they are published or not. The documents may come from teaching and research institutions in France or abroad, or from public or private research centers.
L'archive ouverte pluridisciplinaire HAL, est destinée au dépôt et à la diffusion de documents scientifiques de niveau recherche, publiés ou non, émanant des établissements d'enseignement et de recherche français ou étrangers, des laboratoires publics ou privés. 


\title{
Steam pretreatment of dry and ensiled industrial hemp for ethanol production
}

\author{
Bálint Sipos $^{a, *}$, Emma Kreuger $^{b}$, Sven-Erik Svensson ${ }^{c}$, Kati Réczey ${ }^{a}$, Lovisa Björnsson ${ }^{b}$, \\ Guido Zacchi $^{d}$ \\ ${ }^{a}$ Budapest University of Technology and Economics, Department of Applied Biotechnology and Food Science, Szt. Gellért tér 4., H-1111 \\ Budapest, Hungary \\ ${ }^{\mathrm{b}}$ Lund University, Department of Biotechnology, P.O. Box 124, SE-221 00 Lund, Sweden \\ ${ }^{\mathrm{c}}$ Swedish University of Agricultural Sciences, Department of Agriculture - Farming Systems, Technology and Product Quality, P.O. Box 104, \\ SE-230 53 Alnarp, Sweden \\ ${ }^{\mathrm{d}}$ Lund University, Department of Chemical Engineering, P.O. Box 124, SE-221 00 Lund, Sweden
}

\section{A R T I C L E I N F O}

\section{Article history:}

Received 6 October 2009

Received in revised form

23 June 2010

Accepted 1 July 2010

Available online $\mathrm{xxx}$

Keywords:

Energy crops

Cannabis sativa

Lignocellulose

Enzymatic hydrolysis

SSF

Saccharomyces cerevisiae

\begin{abstract}
A B S T R A C T
Biomass can be converted into liquid and gaseous biofuels with good efficiency. In this study, the conversion of industrial hemp (Cannabis sativa L.), a biomass source that can be cultivated with a high biomass yield per hectare, was used. Steam pretreatment of dry and ensiled hemp was investigated prior to ethanol production. The pretreatment efficiency was evaluated in terms of sugar recovery and polysaccharide conversion in the enzymatic hydrolysis step. For both materials, impregnation with $2 \% \mathrm{SO}_{2}$ followed by steam pretreatment at $210{ }^{\circ} \mathrm{C}$ for $5 \mathrm{~min}$ were found to be the optimal conditions leading to the highest overall yield of glucose. Simultaneous saccharification and fermentation experiments carried out with optimised pretreatment conditions resulted in ethanol yields of $163 \mathrm{~g} \mathrm{~kg}^{-1}$ ensiled hemp (dry matter) (71\% of the theoretical maximum) and $171 \mathrm{~g} \mathrm{~kg}^{-1}$ dry hemp (74\%), which corresponds to $206-216 \mathrm{l} \mathrm{Mg}^{-1}$ ethanol based on initial dry material.

(c) 2010 Elsevier Ltd. All rights reserved.
\end{abstract}

\section{Introduction}

Interest in biomass-based renewable fuels has increased, and ethanol produced from lignocellulosic feedstock is a promising candidate. The carbohydrate portion of lignocellulose biomass (containing cellulose and hemicellulose) is suitable for ethanol production but difficult to access when cellulose, hemicellulose and lignin are associated. Several pretreatment methods have been developed to increase the accessibility of cellulose [1], and a wide variety of lignocellulosic substrates have already been proven to be suitable raw materials, including wood materials (spruce [2], willow [3]), agricultural by-products (such as corn stover [4], wheat straw [5]), sugar production by-products (sugar cane bagasse [6], sweet sorghum bagasse [7]), reeds [8] or switchgrass [9].

The target plant of this study was industrial hemp (Cannabis sativa L.), which is an annual plant mostly cultivated for its strong fibres. Hemp has not, to our knowledge, previously been investigated for ethanol production, and has several features that make it an interesting alternative biomass. The plant is

\footnotetext{
Abbreviations: SPH, steam pretreated hemp; SPHS, steam pretreated hemp silage; WIS, water insoluble solids.

* Corresponding author. Tel.: +36 1463 3442; fax: +36 14633855.

E-mail address: balint_sipos@mkt.bme.hu (B. Sipos).

0961-9534/\$ - see front matter @ 2010 Elsevier Ltd. All rights reserved.
}

doi:10.1016/j.biombioe.2010.07.003 
rather drought tolerant, and can reach high biomass yields per hectare [10]. The need for herbicides can be reduced because hemp is able to overgrow weeds. Thus, it is advantageous to use hemp in a crop rotation, especially in organic farming. Hemp fibre already has many industrial applications, for example in the textile or pulp and paper industries [11]; it can be used in fibre-reinforced composites [12] or as a construction material [13]. Hemp has already been reported to be feasible solid fuel for combustion [14].

Hemp can be cultivated in various climates. In warmer areas, hemp can be dried in the field and stored dry. In other areas where rain is common during the harvest period in the autumn, ensiling can be a more suitable storage method. In addition, during ensiling acids are formed that could later act as catalysts in the physico-chemical pretreatment, which might decrease the need for addition of extra chemicals to the process. When using hemp as a biomass source for fuel production rather than as a fibre crop [15], harvesting should be postponed for 1-2 months to achieve the highest biomass yield.

The cellulose content of the hemp stem is quite high (about $44 \%$ ) compared to other agricultural lignocellulosic materials, e.g., corn stover [16] or wheat straw [5], both with 37\% (dry matter) cellulose. The high cellulose content and high biomass yield make hemp a good potential crop for bioethanol production. The hemp stem consists of bast fibres and a woody core. The bast fibre is rich in cellulose and has rather low lignin content, while the woody core has significantly higher lignin content [17].

Steam pretreatment of hemp fibres has previously been studied in order to separate the fibres from the other components [17]. Treatment with alkali impregnation followed by steam pretreatment at $200^{\circ} \mathrm{C}$ with a residence time of $90 \mathrm{~s}$ was found to be optimal for this purpose. In another study, steam pretreatment of hemp fibres at $185^{\circ} \mathrm{C}$ for 2 min increased the cellulose content from $60 \%$ to $74 \%$, whereas enzyme (pectinase) assisted retting followed by steam pretreatment resulted in a 78\% cellulose content of the remaining solid material [18]. Enhancing the enzymatic breakdown of hemp via electron beam irradiation was previously tested [19], where the improvement in enzymatic hydrolysis was more evident in the hydrolysis of xylan than in that of cellulose.

The aim of the present study was to optimise steam pretreatment parameters for hemp in order to achieve the highest glucose yield in enzymatic hydrolysis for conversion to ethanol. Steam pretreatment was performed both on dry hemp stems and hemp silage (stem and leaves together) under different conditions with and without $\mathrm{SO}_{2}$ impregnation. The efficiency of the pretreatment was evaluated by enzymatic hydrolysis of the whole slurry. Mass balance calculations were performed on the pretreatment and the enzymatic hydrolysis to estimate the overall glucose yield, the efficiency of hemicellulose solubilisation and the sugar degradation. Simultaneous saccharification and fermentation (SSF) was performed on samples at optimised conditions. SSF of both the whole pretreatment slurry and of the separated solid fraction of the pretreated material was performed. Fig. 1 shows the schematic representation of the experiments.

\section{Materials and methods}

\subsection{Raw material}

Industrial hemp (C. sativa L.) of the variety Futura 75 was cultivated at Nöbbelöv, close to Lund, Sweden (N55 $43^{\prime}$, $\left.\mathrm{E} 13^{\circ} 08^{\prime}\right)$. The hemp was sown on 4 April 2007 and harvested on 3 and 4 September. Stems were cut a few centimetres above ground. The average dry matter (DM) yield was $16 \mathrm{Mg} \mathrm{ha}^{-1}$. The hemp was air-dried indoors in open air at $10-20{ }^{\circ} \mathrm{C}$ after harvest to a DM content of $91.7 \%$. There were no visible signs of microbial degradation during drying. Stems and leaves (including fine stems) were separated manually after drying and weighed. Dry stems were comminuted with a garden shredder (AXT $2500 \mathrm{HT}$, Robert Bosch GmbH, Germany) to a length of $2-3 \mathrm{~cm}$. For the steam pretreatment equal amounts of air-dried hemp from three different fertilization levels (115, 150 and $200 \mathrm{~kg} \mathrm{~N} \mathrm{ha}^{-1}$ ) were mixed due to shortage of substrate.

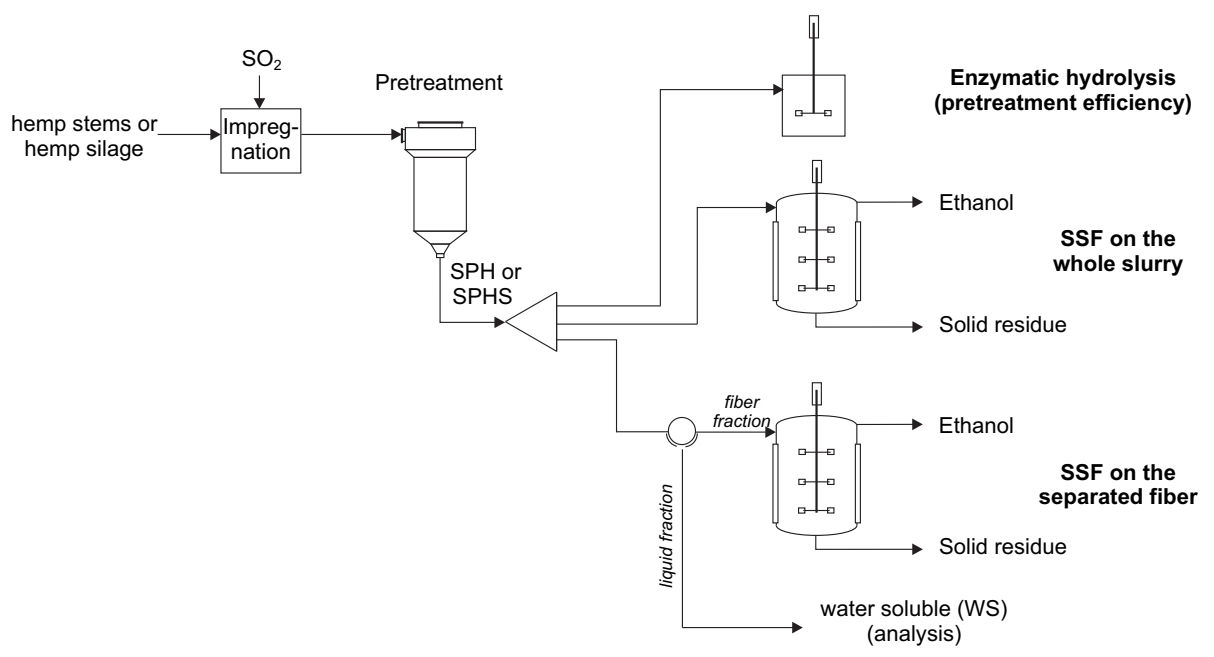

Fig. 1 - Schematic representation of the experimental process (Abbreviations: SPH: steam pretreated hemp, SPHS: steam pretreated hemp silage, SSF: simultaneous saccharification and fermentation). 
The mixture is referred to as dry hemp in the paper. The leaves were not pretreated since they easily fell apart into smaller pieces not suitable for the pretreatment unit used. The stems were sprayed with deionised water to a moisture content of $50 \%$, mixed and stored at room temperature for two days prior to steam pretreatment.

Silage was prepared from hemp (full plant including leaves) fertilized with nitrogen at $200 \mathrm{~kg} \mathrm{ha}^{-1}$, which was harvested and shredded to $\sim 2 \mathrm{~cm}$ pieces using a Claas Jaguar maize forager equipped with a traditional maize header. The hemp was ensiled without additives in round bales made by an Orkel MP 2000 stationary baler. The round bales where wrapped in silage plastic and stored for eight months, from September 2007 to May 2008, when samples were taken from the ensiled hemp. Ensiled hemp samples were stored frozen from May 2008 until pretreatment started (September, 2008). Ensiled hemp (stems and leaves) had oven dry matter content of $25 \%$, therefore no spraying was needed before steam pretreatment.

\subsection{Enzyme preparations}

The enzymes used in the hydrolysis were Celluclast 1.5L and Novozym 188 (Novozymes A/S, Bagsvaerd, Denmark). Filter paper activity of Celluclast $1.5 \mathrm{~L}$ was $60.9 \mathrm{FPU} \mathrm{ml}^{-1}$ and $\beta$-glucosidase activities were $32.8 \mathrm{IU} \mathrm{ml}^{-1}$ and $502.3 \mathrm{IU} \mathrm{ml}^{-1}$ for Celluclast 1.5L and Novozym 188, respectively. FPA and $\beta$-glucosidase activities were measured $[20,21]$ prior to experiments.

\subsection{Chemicals}

Nutrients for fermentations $\left(\mathrm{KH}_{2} \mathrm{PO}_{4},\left(\mathrm{NH}_{4}\right)_{2} \mathrm{SO}_{4}, \mathrm{MgSO}_{4} \cdot 7 \mathrm{H}_{2} \mathrm{O}\right.$ and $\left.\left(\mathrm{NH}_{4}\right)_{2} \mathrm{HPO}_{4}\right)$ were purchased from Merck (Hochenbrun, Germany). Yeast extract was purchased from Applichem (Gatersleben, Germany). 72\% sulphuric acid for analysis of structural carbohydrates was purchased from Fluka (St. Louis, MO, USA). Sugar standards for HPLC analysis were purchased from Sigma-Aldrich (St. Louis, MO, USA).

\subsection{Steam pretreatment}

Pretreatment conditions for dry hemp and ensiled hemp were tested at different temperatures and $\mathrm{SO}_{2}$ impregnation was used when indicated. In the case of dry hemp, three different temperatures $\left(205^{\circ} \mathrm{C}, 210{ }^{\circ} \mathrm{C}\right.$ and $215^{\circ} \mathrm{C}$ ) were investigated with $2 \% \mathrm{SO}_{2}$ impregnation and a 5 -min residence time. Ensiled hemp was pretreated at four temperatures without $\mathrm{SO}_{2}$ impregnation $\left(190^{\circ} \mathrm{C}, 200^{\circ} \mathrm{C}, 210^{\circ} \mathrm{C}\right.$ and $\left.220^{\circ} \mathrm{C}\right)$ and at two temperatures $\left(200^{\circ} \mathrm{C}\right.$ and $210{ }^{\circ} \mathrm{C}$ ) with $2 \% \mathrm{SO}_{2}$ impregnation.

Impregnation was performed in batches of $300 \mathrm{~g}$ dry matter (DM) by injecting $\mathrm{SO}_{2}$ ( $2 \%$ based on water content) into plastic bags. After 20 min of impregnation, the bags were ventilated before the material was steam pretreated. Pretreatment was performed in a $10 \mathrm{l}$ batch reactor, described earlier [22]. After steam pretreatment, the slurry was collected from the flash cyclone and stored at $+5^{\circ} \mathrm{C}$ a few days. There were no visible signs of microbial degradation during storage. Samples for analysis were washed with distilled water to remove water soluble from water-insoluble solids (WIS). A part of the pretreatment slurry was separated into solid and liquid fractions using a manual hydraulic press (Sixten Torne AB, Malmö, Sweden). The solid fraction was used for the SSF without additional washing step in the case, when only the solid fraction was used, and the liquid was used for the yeast cultivation (as described in Section 2.5).

\subsection{Enzymatic hydrolysis}

Enzymatic hydrolysis was performed to evaluate the effect of different steam pretreatment conditions. A low substrate concentration ( $2 \%$ water-insoluble solids (WIS) using the whole pretreatment slurry) was used to minimise product inhibition. Enzyme loading for hydrolysis was $15 \mathrm{FPU} \mathrm{g}^{-1}$ WIS Celluclast 1.5L and $23 \mathrm{IU} \mathrm{g}^{-1}$ WIS Novozym 188. The hydrolysis was performed with $500 \mathrm{~g}$ total mass in 11 bottles immersed in a water bath at $40{ }^{\circ} \mathrm{C}$. Agitation with a frequency of $5 \mathrm{~Hz}$ was ensured by overhead stirring. The $\mathrm{pH}$ was set to 4.8 with a $0.05 \mathrm{~mol} \mathrm{l}^{-1}$ sodium acetate buffer. Samples were taken after $0,2,4,8,24,48,72$ and $96 \mathrm{~h}$ and analysed for monomer sugar content by high-performance liquid chromatography (HPLC). All hydrolysis experiments were run in duplicate.

\subsection{Yeast cultivation}

Yeast cultivation was performed in three steps (propagation, batch and fed-batch cultivation) [5]. The strain of Saccharomyces cerevisiae used was purified from commercial yeast (Jästbolaget $A B$, Rotebro, Sweden). Cells were added to a $300 \mathrm{ml}$ Erlenmeyer flask with $70 \mathrm{ml}$ of a water solution containing $23.8 \mathrm{~g} \mathrm{l}^{-1}$ glucose, $10.8 \mathrm{~g} \mathrm{l}^{-1}\left(\mathrm{NH}_{4}\right)_{2} \mathrm{SO}_{4}, 5.0 \mathrm{~g} \mathrm{l}^{-1}$ $\mathrm{KH}_{2} \mathrm{PO}_{4}$ and $1.1 \mathrm{~g} \mathrm{l}^{-1} \mathrm{MgSO}_{4} \cdot 7 \mathrm{H}_{2} \mathrm{O}$. The water solution also contained $14.4 \mathrm{ml} \mathrm{l}^{-1}$ of a trace-metal solution and $1.4 \mathrm{ml} \mathrm{l}^{-1}$ of a vitamin solution [23]. The $\mathrm{pH}$ was adjusted to $\mathrm{pH} 5$ with $0.25 \mathrm{~mol} \mathrm{l}^{-1} \mathrm{NaOH}$. The Erlenmeyer flask was closed with a cotton plug and incubated at $30^{\circ} \mathrm{C}$ for $24 \mathrm{~h}$ on an incubator shaker using an agitation frequency of $2.5 \mathrm{~Hz}$.

Batch cultivation was then performed in a 21 fermenter (Infors AG, Bottmingen, Switzerland) with a working volume of $250 \mathrm{ml}$, similarly to the procedure described earlier [24] with some modifications. Cultivation was started by adding a $60 \mathrm{ml}$ inoculum to a medium containing $40.0 \mathrm{~g} \mathrm{l}^{-1}$ glucose, $22.5 \mathrm{~g} \mathrm{l}^{-1}$ $\left(\mathrm{NH}_{4}\right)_{2} \mathrm{SO}_{4}, 10.5 \mathrm{~g} \mathrm{l}^{-1} \mathrm{KH}_{2} \mathrm{PO}_{4}, 2.2 \mathrm{~g} \mathrm{l}^{-1} \mathrm{MgSO}_{4} \cdot 7 \mathrm{H}_{2} \mathrm{O}, 60.0 \mathrm{ml} \mathrm{l}^{-1}$ trace-metal solution and $6.0 \mathrm{ml} \mathrm{l}^{-1}$ vitamin solution [23]. The $\mathrm{pH}$ was continuously adjusted to $\mathrm{pH} 5$ with $10 \% \mathrm{NaOH}$ solution. The stirring frequency was $8.3 \mathrm{~Hz}$ and the aeration rate was $0.251 \mathrm{~min}^{-1}$ corresponding to a space velocity of $1 \mathrm{~min}^{-1}$. The dissolved oxygen concentration was continuously measured throughout batch cultivation with an oxygen sensor. Batch cultivation was changed to fed-batch cultivation when a rapid increase in oxygen concentration was observed.

Fed-batch cultivation was performed on the liquid fraction of the pretreatment slurry by continuous addition of $858 \mathrm{ml}$ of liquid fraction supplemented with glucose and salt solutions to a total volume of $1000 \mathrm{ml}$. The glucose concentration in the pretreatment liquid solution was adjusted to $80 \mathrm{~g} \mathrm{l}^{-1}$. Salts were added to the solution to concentrations of $11.3 \mathrm{~g} \mathrm{l}^{-1}$ $\left(\mathrm{NH}_{4}\right)_{2} \mathrm{SO}_{4}, 5.3 \mathrm{gl}^{-1} \mathrm{KH}_{2} \mathrm{PO}_{4}$ and $1.1 \mathrm{gl}^{-1} \mathrm{MgSO}_{4} \cdot 7 \mathrm{H}_{2} \mathrm{O}$. The final concentration of the diluted liquid fraction was equivalent to that obtained when the slurry from pretreatment had been diluted to $7.5 \%$ WIS. The diluted and adjusted liquid fraction 
was added to the fermenter at constant flow rate for $14-16 \mathrm{~h}$. The $\mathrm{pH}$ was continuously adjusted to 5 with $10 \% \mathrm{NaOH}$ solution. The stirring frequency was $13.3 \mathrm{~Hz}$ and the aeration rate was $1.875 \mathrm{l} \mathrm{min} \mathrm{m}^{-1}$ at the end of the fed-batch cultivation, corresponding to $1.5 \mathrm{~min}^{-1}$ space velocity. Cells were harvested by centrifugation of the broth at $150 \mathrm{~Hz}$ for $5 \mathrm{~min}$ and were washed two times with deionised water.

\subsection{SSF}

SSF experiments were performed in 21 laboratory fermenters (Infors AG, Bottmingen, Switzerland) with $1.4 \mathrm{~kg}$ of working mass using $7.5 \%$ WIS substrate concentration. As nutrients $0.5 \mathrm{gl}^{-1}\left(\mathrm{NH}_{4}\right)_{2} \mathrm{HPO}_{4}, 0.025 \mathrm{~g} \mathrm{l}^{-1} \mathrm{MgSO}_{4}$ and $1 \mathrm{gl}^{-1}$ yeast extract were added. The fermenter with the substrate and the nutrients in separate bottles were sterilised at $121^{\circ} \mathrm{C}$ for $20 \mathrm{~min}$. Cultivated yeast was added at a concentration of $5 \mathrm{gl}^{-1}$. The experiments were performed at $37^{\circ} \mathrm{C}$ and $\mathrm{pH} 5$, maintained using a $10 \% \mathrm{NaOH}$ solution. The experiments were run for $72 \mathrm{~h}$ with $5.8 \mathrm{~Hz}$ agitation. Enzyme loading was $20 \mathrm{FPU} \mathrm{g}^{-1}$ glucan Celluclast 1.5L and $23 \mathrm{IU} \mathrm{g}^{-1}$ glucan Novozym 188. SSF experiment samples were analysed by HPLC for sugars, lactic acid, acetic acid and ethanol content.

\subsection{Analysis}

Extractive contents of the dry hemp samples were determined according to the NREL protocol [25], with the modification that samples were dried at $105^{\circ} \mathrm{C}$ before and after extraction and the extractives were calculated as loss in weight by the samples. Analysis of structural carbohydrates and lignin (based on DM) were performed on the extracted dry hemp stem samples as well as on the solid fraction of the silage and on the solid fractions after pretreatment. The analyses were performed according to the NREL protocol [26]. Silage and solid fractions were washed with distilled water prior to analysis. The content of various sugars in the liquid fractions after steam pretreatment and in the liquid fraction of the untreated silage, obtained by filtration, was analysed according to the NREL protocol [27]. The difference in monomer sugar concentrations with and without dilute acid hydrolysis of the liquid samples was determined as oligomer sugars. Each sample was analysed in duplicate.

\subsection{HPLC}

The carbohydrate and inhibitor content in the liquid samples were analysed with an HPLC system (Shimadzu, Japan) equipped with a refractive index detector. An Aminex HPX$87 \mathrm{H}$ column (Bio-Rad, Hercules, CA, USA) was used for the separation and determination of cellobiose, glucose, mannose, arabinose, lactic acid, glycerol, acetic acid, ethanol,

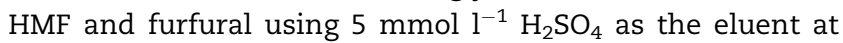
a flow rate of $0.5 \mathrm{ml} \mathrm{min}{ }^{-1}$ and a column temperature of $65^{\circ} \mathrm{C}$. An Aminex HPX-87P column (Bio-Rad, Hercules, CA, USA) was used for the separation of cellobiose, glucose, xylose, galactose, arabinose and mannose with Millipore quality water as the eluent at a $0.6 \mathrm{ml} \mathrm{min}^{-1}$ flow rate and a column temperature of $85{ }^{\circ} \mathrm{C}$. Calibration of the equipment for each compound was performed with 6 level calibration standards at a range of $0.15-10.0 \mathrm{mg} \mathrm{ml}^{-1}$.

\subsection{Mass balance calculations}

During the experiments, process streams were quantified and analysed as described above.

The "volatile/further degraded" fraction in the mass balances was calculated on the basis of the difference in total solids loaded to the reactor and collected from the cyclone. The mass balance calculation includes all measurement errors from the process.

\subsection{Statistical evaluation}

The effect of fertilization and ensiling on the composition of hemp stems and solid fraction of hemp silage was investigated using Statistica 8.0 software (Statsoft Inc., Tulsa, OK, USA) One-way ANOVA followed by Tukey's HSD test was used for multiple comparison of the fibre characteristics between treatments.

Table 1 - Composition of dry hemp grown at different fertilization levels and solid fraction of hemp silage as percentage of dry weight. Mean values of duplicates are presented. Relative standard deviations in percentage are indicated in parenthesis.

\begin{tabular}{|c|c|c|c|c|}
\hline & $\begin{array}{c}\text { Dry hemp } \\
\text { (115 kg ha }{ }^{-1} \text { fertilizer) }\end{array}$ & $\begin{array}{c}\text { Dry hemp } \\
\text { (150 kg ha }{ }^{-1} \text { fertilizer) }\end{array}$ & $\begin{array}{c}\text { Dry hemp } \\
\text { (200 kg ha }{ }^{-1} \text { fertilizer) }\end{array}$ & $\begin{array}{l}\text { Solid fraction of } \\
\text { hemp silage }\end{array}$ \\
\hline Glucan & $44.1(3.6 \%)$ & 43.7 (1.9\%) & $43.0(2.7 \%)$ & $45.2(0.4 \%)$ \\
\hline Mannan & $2.0(3.4 \%)$ & $2.1(1.0 \%)$ & 1.8 (1.7\%) & $2.6(0.2 \%)$ \\
\hline Xylan & $10.1(4.5 \%)$ & $11.0(1.5 \%)$ & $10.3(2.8 \%)$ & $10.1(3.4 \%)$ \\
\hline Galactan & $2.1(4.4 \%)$ & $2.0(0.4 \%)$ & $2.1(1.7 \%)$ & $1.7(0.2 \%)$ \\
\hline Arabinan & $0.7(4.8 \%)$ & $0.6(2.5 \%)$ & $0.7(1.4 \%)$ & b.d.l. \\
\hline Acid-soluble lignin & $6.5(0.3 \%)$ & $6.7(0.1 \%)$ & $6.7(7.2 \%)$ & $4.7(3.7 \%)$ \\
\hline Acid-insoluble lignin & $14.5(0.2 \%)$ & $15.0(1.3 \%)$ & $15.3(0.4 \%)$ & $18.7(2.1 \%)$ \\
\hline Water extractives & 13.5 & 11.9 & 11.0 & n.d. \\
\hline Ethanol extractives & 2.7 & 1.4 & 0.8 & n.d. \\
\hline Total determined compounds & 96.1 & 94.3 & 91.6 & 83.0 \\
\hline
\end{tabular}




\section{Results and discussion}

\subsection{Raw material compositions}

Three samples of dry hemp (only stems) from different nitrogen-fertilization levels and solid fraction of hemp silage were analysed for their composition (see Table 1). One-way ANOVA was performed to compare the fibre composition of hemp fertilized with different nitrogen levels and hemp silage. The statistical analysis has shown, that the effect of these treatments for carbohydrate content, i.e. glucan and xylan, was not significant ( $p=0.16$ and 0.48 , respectively at 95\% confidence limit). For acid-soluble lignin and acid-insoluble lignin, the statistical analysis has shown, that that there was a significant difference in lignin content of the materials ( $p=0.005$ and 0.0001 , respectively at $95 \%$ confidence limit). Tukey's HSD test showed that the silage had a significantly different content of both acid-soluble lignin and acid-insoluble lignin while the content was not significantly different in the three samples with different fertilization level. The difference in acid-insoluble lignin content of the silage might be due to that no extractive measurement was performed on hemp silage, which may give an overestimation of this fraction. A mixture of the three dry hemp samples (equal parts of stem samples) was used for steam pretreatment due to the shortage of the feedstock. The composition used during the calculations is the average of the compositions in Table 1. The liquid fraction of hemp silage had a pH of 4.5 and contained four main components: $17.6 \mathrm{~g} \mathrm{l}^{-1}$ lactic acid, $7.6 \mathrm{~g} \mathrm{l}^{-1}$ acetic acid, $3.0 \mathrm{~g} \mathrm{l}^{-1}$ glucose and $1.2 \mathrm{~g} \mathrm{l}^{-1}$ ethanol. The dominance of lactate and acetate as fermentation products and the low $\mathrm{pH}$ indicate that the silage was well preserved.

\subsection{Composition of WIS after pretreatment}

Pretreatment of hemp stem using $2 \% \mathrm{SO}_{2}$ impregnation was performed at 205, 210 and $215^{\circ} \mathrm{C}$. Previous studies at Lund University, Department of Chemical Engineering, suggested
Table 2 - DM and WIS contents of pretreated slurry and composition of washed WIS fraction of steam pretreated ( $2 \% \mathrm{SO}_{2}$ impregnation) dry hemp (SPH). WIS compositions are presented as percentage of dry weight. Mean values of duplicates are presented. Relative standard deviations in percentage are indicated in parenthesis.

\begin{tabular}{|c|c|c|c|}
\hline & $205^{\circ} \mathrm{C}$ & $210^{\circ} \mathrm{C}$ & $215^{\circ} \mathrm{C}$ \\
\hline DM [\%] & 15.1 & 11.3 & 10.9 \\
\hline WIS [\%] & 12.4 & 8.2 & 8.3 \\
\hline Glucan & $66.8(5.3 \%)$ & $66.8(4.5 \%)$ & $64.7(3.0 \%)$ \\
\hline Mannan & $2.1(0.6 \%)$ & 1.8 (1.9\%) & 1.4 (0.4\%) \\
\hline Xylan & $3.8(3.0 \%)$ & $3.0(2.0 \%)$ & 2.7 (1.5\%) \\
\hline Galactan & $0.7(4.8 \%)$ & b.d.l. & b.d.l. \\
\hline Arabinan & $0.2(3.9 \%)$ & b.d.l. & b.d.l. \\
\hline Acid-soluble lignin & $3.8(3.8 \%)$ & 3.7 (3.1\%) & $3.7(1.3 \%)$ \\
\hline Acid-insoluble lignin & $19.3(5.2 \%)$ & $21.2(0.3 \%)$ & $25.9(1.4 \%)$ \\
\hline Lignin ash & $0.3(3.7 \%)$ & $0.4(6.9 \%)$ & $0.4(3.5 \%)$ \\
\hline $\begin{array}{l}\text { Total determined } \\
\text { compounds }\end{array}$ & 96.8 & 96.7 & 98.8 \\
\hline
\end{tabular}

that $\mathrm{SO}_{2}$ impregnation and a temperature above $200{ }^{\circ} \mathrm{C}$ is needed for sufficient pretreatment of dry hemp (data not published). Table 2 shows the composition of the WIS fractions from the steam pretreated hemp stem (SPH). The solid fraction was mainly composed of glucan (65-67\%) and lignin (25-30\%) while hemicellulose was solubilised to a large extent. Only small differences in WIS composition were observed after steam pretreatment at $205-215^{\circ} \mathrm{C}$ with $\mathrm{SO}_{2}$ impregnation.

Steam pretreatment of hemp silage was performed both with and without $\mathrm{SO}_{2}$ impregnation. $\mathrm{A}$ wide range of pretreatment temperatures $\left(190-220^{\circ} \mathrm{C}\right.$ ) were tested due to the scarce available knowledge on steam pretreatment of ensiled materials. Compositions of the WIS of the steam pretreated hemp silage (SPHS) are presented in Table 3. At milder pretreatment conditions without $\mathrm{SO}_{2}$ impregnation (190 and $\left.200{ }^{\circ} \mathrm{C}\right)$, the solubilisation of the hemicellulose was not sufficient; a significant amount of xylan was present in the WIS

Table 3 - DM and WIS contents of pretreated slurry and composition of washed WIS fraction of steam pretreated hemp silage (SPHS). WIS compositions are presented as percent of dry weight. Mean values of duplicates are presented. Relative standard deviations in percentage are indicated in parenthesis.

\begin{tabular}{|c|c|c|c|c|c|c|}
\hline \multirow{3}{*}{ DM [\%] } & \multicolumn{4}{|c|}{ no $\mathrm{SO}_{2}$} & \multicolumn{2}{|c|}{$\mathrm{SO}_{2}$} \\
\hline & $190^{\circ} \mathrm{C}$ & $200^{\circ} \mathrm{C}$ & $210^{\circ} \mathrm{C}$ & $220^{\circ} \mathrm{C}$ & $200^{\circ} \mathrm{C}$ & $210^{\circ} \mathrm{C}$ \\
\hline & 8.8 & 10.7 & 10.9 & 10.8 & 12.6 & 11.0 \\
\hline WIS [\%] & 6.2 & 7.5 & 7.4 & 7.1 & 7.8 & 7.5 \\
\hline Glucan & $57.9(5.8 \%)$ & $62.4(1.7 \%)$ & $67.1(1.8 \%)$ & $60.7(2.3 \%)$ & $68.7(1.2 \%)$ & $66.0(0.0 \%)$ \\
\hline Mannan & $2.7(9.3 \%)$ & $2.5(1.0 \%)$ & $2.2(0.0 \%)$ & $1.8(4.5 \%)$ & $2.2(4.6 \%)$ & $1.8(2.5 \%)$ \\
\hline Xylan & $8.4(5.2 \%)$ & $7.5(0.1 \%)$ & $1.3(2.5 \%)$ & $0.6(4.6 \%)$ & $1.3(4.2 \%)$ & $0.4(0.2 \%)$ \\
\hline Galactan & $1.0(2.8 \%)$ & $0.7(0.4 \%)$ & $0.7(5.5 \%)$ & $0.5(2.6 \%)$ & $0.7(0.7 \%)$ & $0.8(1.2 \%)$ \\
\hline Arabinan & b.d.l. & b.d.l. & b.d.l. & b.d.l. & b.d.l. & b.d.l. \\
\hline Acid-soluble lignin & $3.6(6.4 \%)$ & $3.2(3.0 \%)$ & $2.9(3.3 \%)$ & $3.3(6.6 \%)$ & $2.8(0.3 \%)$ & $2.9(1.0 \%)$ \\
\hline Acid-insoluble lignin & $19.4(8.2 \%)$ & $19.1(6.8 \%)$ & $23.4(0.5 \%)$ & $26.0(0.8 \%)$ & $21.0(0.7 \%)$ & $24.7(5.6 \%)$ \\
\hline Lignin ash & $2.0(2.3 \%)$ & $1.5(2.5 \%)$ & $1.3(3.8 \%)$ & $2.3(1.7 \%)$ & $1.6(2.9 \%)$ & $0.5(3.6 \%)$ \\
\hline Total determined compounds & 94.9 & 96.8 & 98.9 & 95.2 & 98.0 & 97.1 \\
\hline
\end{tabular}

b.d.l. - below detection limit 


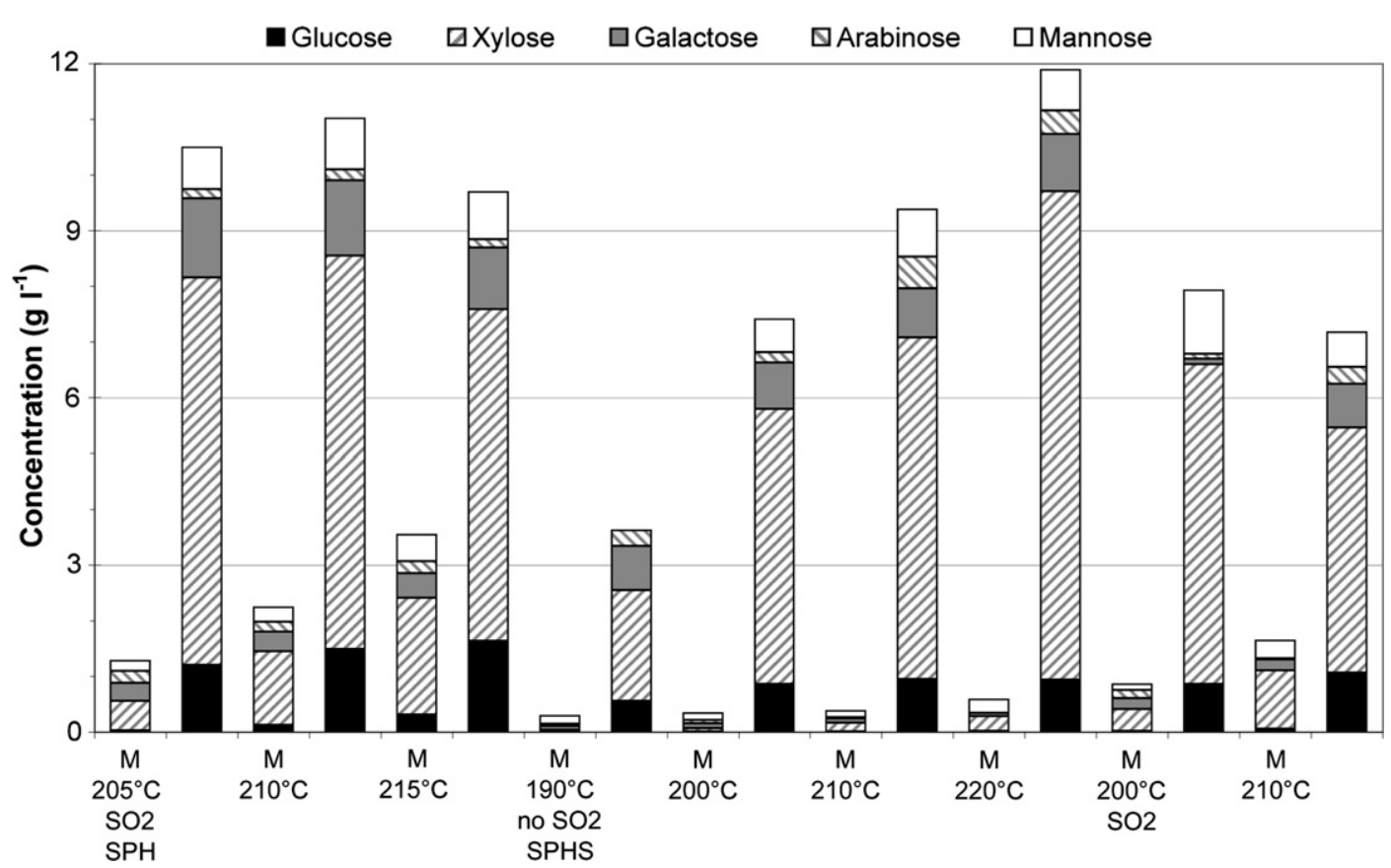

Fig. 2 - Concentrations of monomer (M) and oligomer $(0)$ sugars $\left(\mathrm{g} \mathrm{l}^{-1}\right)$ detected in the liquid fractions of SPH and SPHS (oligomers were measured as monomers after dilute acid hydrolysis, and are presented here as concentrations of monomers).

fraction after pretreatment. At higher temperatures, the xylan content of the WIS decreased to below 1.5\%. However, the lower glucan content in case of the $220^{\circ} \mathrm{C}$ treatment (without $\mathrm{SO}_{2}$ impregnation) compared to the $210{ }^{\circ} \mathrm{C}$ (with or without $\mathrm{SO}_{2}$ ) suggests that using this high temperature, the cellulose component of the solid fraction was partly solubilised or degraded during the pretreatment. It should also be noted that the SPHS slurry had a strong unpleasant smell after pretreatment, in contrast to the SPH slurry.

\subsection{Composition of liquid fraction after pretreatment}

Fig. 2 shows the sugar concentrations of monomeric and oligomeric sugars in the liquid fractions of the steam pretreated materials. The oligomeric sugars were detected at significantly higher concentrations than the monomeric sugars. In case of SPH the presence of the oligomers glucose, galactose and mannose were around 1.0-1.5 g $\mathrm{l}^{-1}$ (expressed in monomeric concentration), while the oligomeric xylan concentration was $6.0-7.0 \mathrm{~g} \mathrm{l}^{-1}$. These data suggest that during the steam pretreatment the hemicellulose fraction of the hemp stem was solubilised, but not degraded to monomeric sugars. In case of SPHS, similar trends were observed, but generally with lower oligomeric sugar concentrations. In general terms, the harsher pretreatments yielded higher sugar concentrations in the supernatants.

Concentrations of 5-hydroxymethyl-furfural (HMF) and furfural (degradation products of C6 and C5 sugars, respectively) were below reported inhibiting levels for ethanol fermentation [28] for all samples except SPH treated at $215^{\circ} \mathrm{C}$ with $\mathrm{SO}_{2}$ (Table 4). The low concentration of these sugar degradation products suggests that degradation of

Table 4 - Concentrations of organic acids and inhibitory compounds in $\mathrm{g}^{-1}$ measured in the liquid fractions of pretreated SPH, SPHS and untreated hemp silage.

\begin{tabular}{|c|c|c|c|c|c|}
\hline & & Lactic acid $\left(\mathrm{g} \mathrm{l}^{-1}\right)$ & Acetic acid $\left(\mathrm{g} \mathrm{l}^{-1}\right)$ & $\operatorname{HMF}\left(\mathrm{g} \mathrm{l}^{-1}\right)$ & Furfural $\left(\mathrm{g} \mathrm{l}^{-1}\right)$ \\
\hline \multirow[t]{3}{*}{ SPH } & $205^{\circ} \mathrm{C} \mathrm{SO}_{2}$ & 0.21 & 1.27 & 0.08 & 0.29 \\
\hline & $210^{\circ} \mathrm{C} \mathrm{SO}_{2}$ & 0.31 & 1.93 & 0.16 & 0.51 \\
\hline & $215^{\circ} \mathrm{C} \mathrm{SO}_{2}$ & 0.57 & 3.15 & 0.31 & 0.93 \\
\hline \multirow[t]{7}{*}{ SPHS } & untreated & 17.6 & 7.6 & 0.18 & b.d.l. \\
\hline & $190^{\circ} \mathrm{C}$ & 4.86 & 2.20 & 0.09 & 0.06 \\
\hline & $200^{\circ} \mathrm{C}$ & 5.90 & 3.21 & 0.05 & 0.12 \\
\hline & $210^{\circ} \mathrm{C}$ & 6.10 & 4.02 & 0.07 & 0.22 \\
\hline & $220^{\circ} \mathrm{C}$ & 5.47 & 5.00 & 0.09 & 0.55 \\
\hline & $200^{\circ} \mathrm{C} \mathrm{SO}_{2}$ & 6.85 & 3.88 & 0.07 & 0.21 \\
\hline & $210^{\circ} \mathrm{C} \mathrm{SO}_{2}$ & 6.26 & 4.49 & 0.15 & 0.54 \\
\hline
\end{tabular}


Table 5 - Sugar concentrations, glucan conversions in enzymatic hydrolysis (expressed as percentage of the theoretical) and the overall glucose yield (including both pretreatment and enzymatic hydrolysis) for SPH and SPHS substrates pretreated at different conditions. Mean values of duplicate experiments and standard deviations are presented.

\begin{tabular}{llccc} 
& Glucose $\left(\mathrm{g} \mathrm{l}^{-1}\right)$ & Glucan conversion (\%) & Overall glucose yield ${ }^{\mathrm{a}}\left(\mathrm{g} \mathrm{kg}^{-1} \mathrm{raw} \mathrm{material)}\right.$ \\
\hline $\mathrm{SPH}$ & $205^{\circ} \mathrm{C} \mathrm{SO}_{2}$ & $10.9 \pm 2.4$ & $72.4 \pm 1.4$ & $328.9 \pm 6.4$ \\
& $210^{\circ} \mathrm{C} \mathrm{SO}_{2}$ & $12.7 \pm 1.4$ & $83.1 \pm 1.0$ & $373.3 \pm 4.5$ \\
\multirow{3}{*}{$\mathrm{SPHS}$} & $215^{\circ} \mathrm{C} \mathrm{SO}_{2}$ & $13.3 \pm 0.9$ & $87.6 \pm 6.9$ & $383.1 \pm 30.1$ \\
& $190^{\circ} \mathrm{C}$ & $8.4 \pm 0.6$ & $64.0 \pm 5.3$ & $254.8 \pm 21.1$ \\
& $200^{\circ} \mathrm{C}$ & $8.3 \pm 0.4$ & $58.3 \pm 2.9$ & $325.8 \pm 12.8$ \\
& $210^{\circ} \mathrm{C}$ & $10.8 \pm 0.7$ & $71.0 \pm 1.4$ & $318.5 \pm 8.4$ \\
& $220^{\circ} \mathrm{C}$ & $10.6 \pm 0.3$ & $78.6 \pm 2.0$ & $341.8 \pm 13.7$ \\
& $200^{\circ} \mathrm{C} \mathrm{SO}_{2}$ & $11.7 \pm 0.5$ & $74.7 \pm 3.0$ & $372.3 \pm 8.3$ \\
\hline
\end{tabular}

${ }^{a}$ for SPHS, the base of the glucose yield was ensiled hemp.

monomeric sugars from hemicellulose was not significant during the pretreatment. The ratio of sugar degradation products based on the raw material were below $1.2 \mathrm{~g} \mathrm{~kg}^{-1}$ for $\mathrm{HMF}$ and $2.0 \mathrm{~g} \mathrm{~kg}^{-1}$ for furfural based on untreated material, except for $215{ }^{\circ} \mathrm{C} \mathrm{SO}_{2}$ (SPH), $220{ }^{\circ} \mathrm{C}$ and $210{ }^{\circ} \mathrm{C} \mathrm{SO}_{2}$ (SPHS), where $3.7-4.5 \mathrm{~g} \mathrm{~kg}^{-1}$ furfural formation was observed.

A slight lactic acid formation was observed in case of $\mathrm{SPH}$, while a significantly higher amount was detected in the supernatant of SPHS, which likely originated from the ensiling process. The concentration of acetic acid released during the pretreatment of hemp stem was measured at 1.2-3.1 $\mathrm{g} \mathrm{l}^{-1}$. In case of SPHS, it was significantly higher, up to $5 \mathrm{~g} \mathrm{l}^{-1}$, which corresponds to $1.8-4.1 \%$ of the initial raw material. Acetic acid originates both from the ensiling and from the acetyl groups in the hemicellulose released during the pretreatment. Weak acids have previously been found to have an inhibitory effect on ethanol production by S. cerevisiae [29].

\subsection{Enzymatic hydrolysis}

Enzymatic hydrolysis of the pretreated slurry was performed to evaluate the accessibility of the cellulose and thus the efficiency of the pretreatments. Enzymatic hydrolysis was performed on the pretreated slurries of SPH and SPHS. Table 5 shows the final glucose concentrations and the glucan conversions in the enzymatic hydrolysis as well as the overall glucose yield including both pretreatment and enzymatic hydrolysis. For SPH pretreatment at $215{ }^{\circ} \mathrm{C}$ resulted in the highest glucan conversion and overall glucose yield, but it should be kept in mind that this material contained high concentrations of furfural and HMF and thus the ethanol fermentation might be significantly inhibited. Pretreatment at $210^{\circ} \mathrm{C}$ gave nearly as high glucan conversion and glucose yield but lower levels of inhibitors. For SPHS pretreatment at $210{ }^{\circ} \mathrm{C}$ for $5 \mathrm{~min}$ with $\mathrm{SO}_{2}$ addition gave the highest overall glucose yield among the conditions investigated. Lower temperatures and pretreatments without catalyst resulted insufficient glucan conversion, therefore lower glucan yields. For both SPH and SPHS pretreatment at $210^{\circ} \mathrm{C}$ using $\mathrm{SO}_{2}$ catalyst resulted in a considerable increase in glucan breakdown, resulting in a glucose yield of 373 and $372 \mathrm{~g} \mathrm{~kg}^{-1}$, respectively.

Although hydrolysis was performed using equal substrate concentrations ( $2 \%$ WIS), higher glucose concentration does not necessarily mean higher glucan conversion, as the compositions of the WIS fractions differ (Tables 2 and 3). The availability of the glucan varied in different samples, for instance in the case of SPHS pretreated without $\mathrm{SO}_{2}$ at $210{ }^{\circ} \mathrm{C}$, where the glucan content of the WIS was as high as for the $\mathrm{SPH}$ treated with $\mathrm{SO}_{2}$ at the same temperature (data in Tables 2 and 3), and the conversion was significantly lower for SPHS (Table 5).

Fig. 3 shows conversion values reached in enzymatic hydrolysis as a function of pretreatment temperature. When $\mathrm{SO}_{2}$ impregnation was applied (closed symbols), the increase of the temperature resulted in more remarkable increased glucan conversion compared to pretreatments without the acid catalyst.

\subsection{Mass balance analysis}

Mass balance analyses were performed for both the pretreatment alone and in combination with enzymatic hydrolysis. Fig. 4A and B show the carbohydrate recoveries after steam pretreatment for hemp stem and hemp silage, respectively. In the calculations for the pretreatment, the amount of ensiled hemp was taken as $100 \%$, i.e., possible loss during ensiling was not taken into consideration. The exact

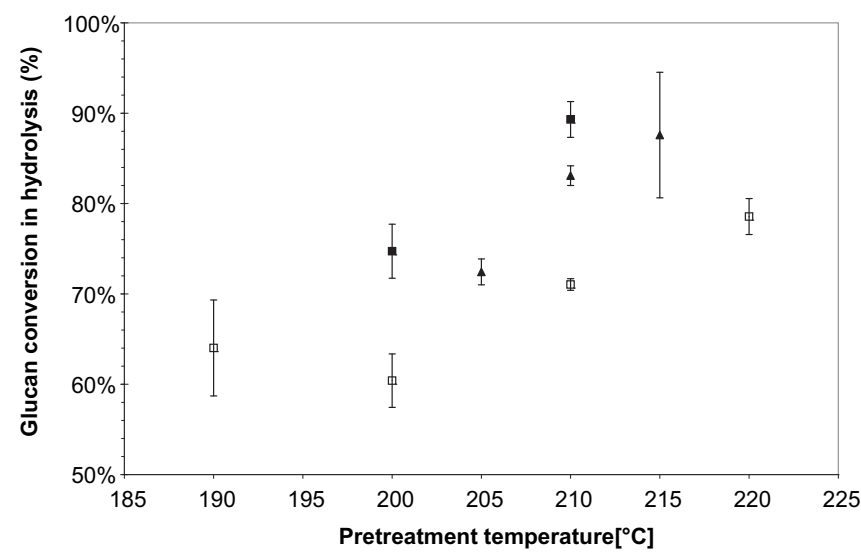

Fig. 3 - Glucan conversion in enzymatic hydrolysis of steam pretreated hemp and hemp silage as a function of pretreatment temperature. Mean values of duplicate experiments and standard deviations are presented (steam pretreated hemp with $\mathrm{SO}_{2}(\Delta)$; steam pretreated hemp silage with ( $\square$ ) and without ( $\square$ ) $\mathrm{SO}_{2}$ ). 


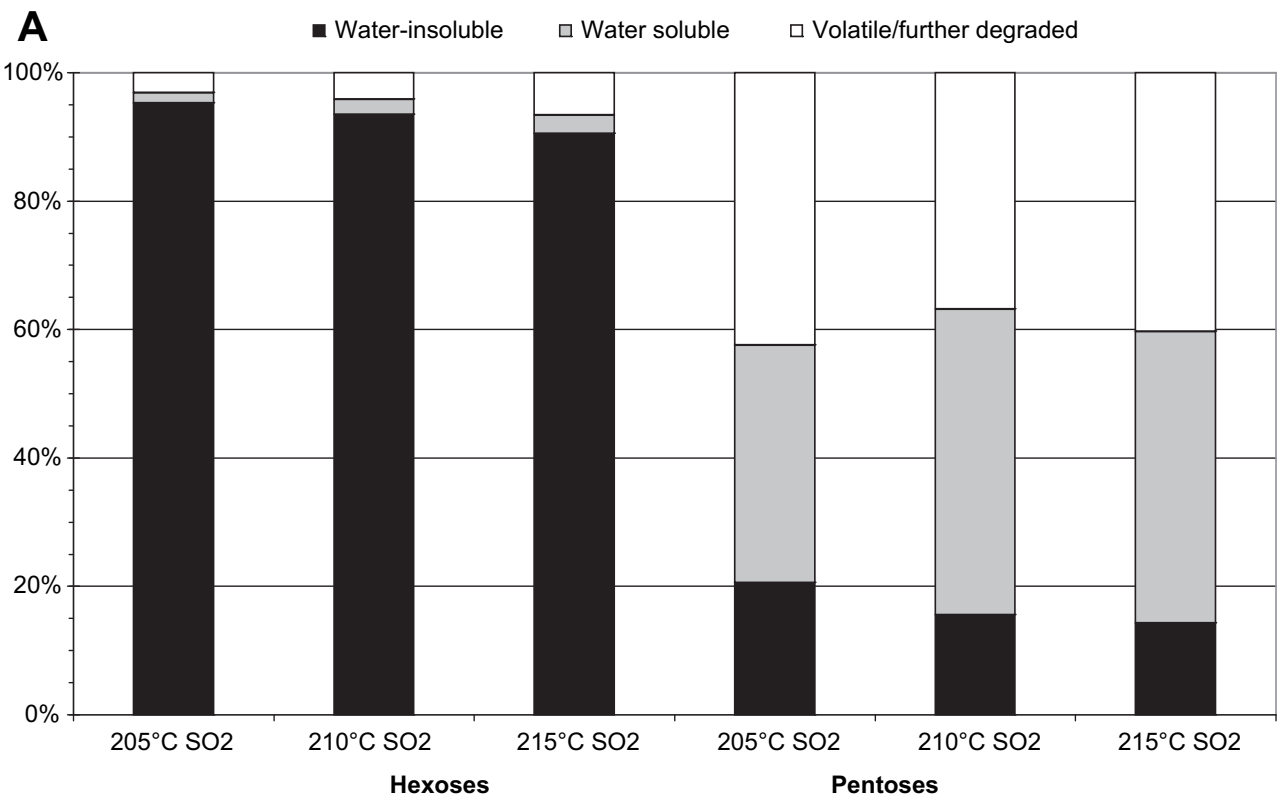

B

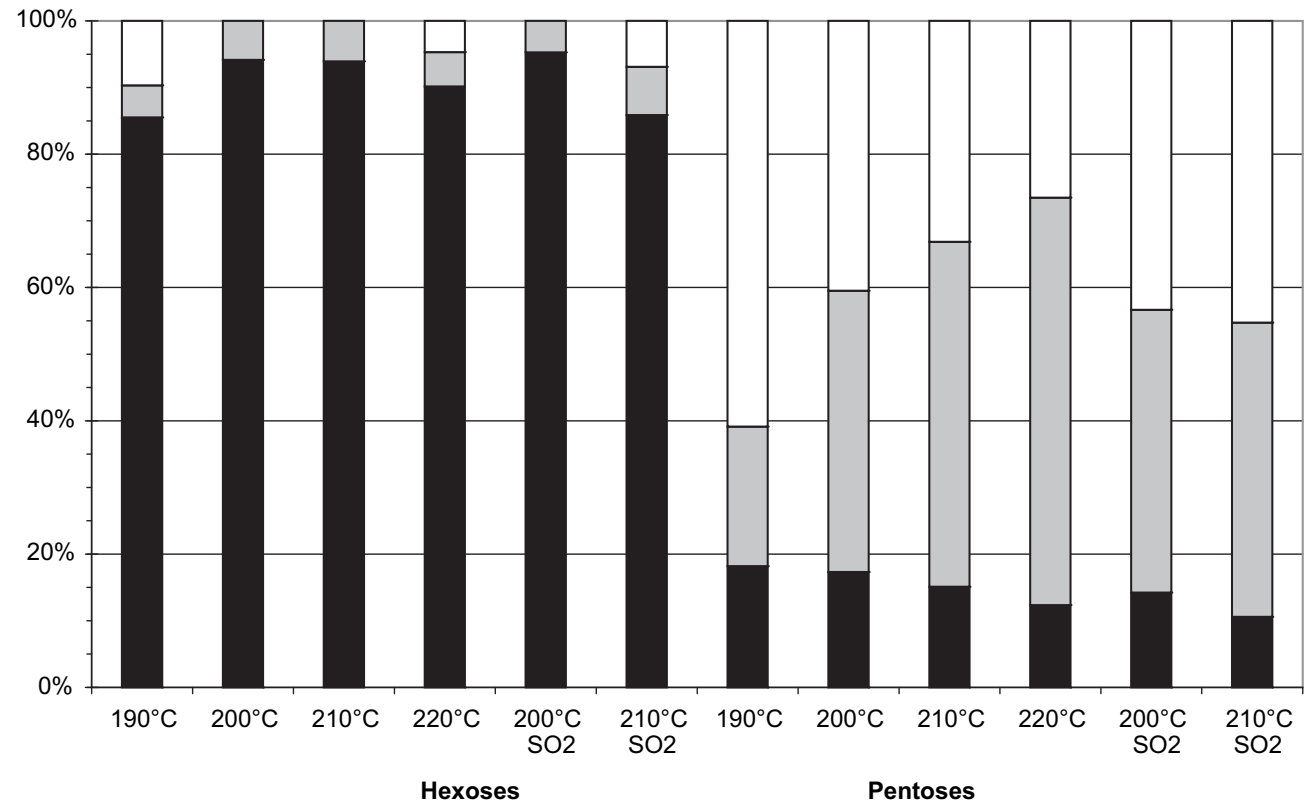

Fig. 4 - Hexose and pentose recoveries after steam pretreatment of dry hemp (A) and hemp silage (B) as percentage of the theoretical. Values are based on carbohydrates in the raw material.

change in DM and energy content during ensiling is difficult to determine if the mass and composition of the material is not determined before and after ensiling [30]. The mass was not determined in the farm scale ensiling used. Based on the amount of solubilised sugars and fermentation products (i.e. lactic acid, acetic acid, glucose and ethanol) measured in the liquid of the silage, a rough estimation of the material balance of ensiling can be performed, which shows that during the ensiling, approximately $8 \%$ of the raw material was turned into these products.

$\mathrm{SPH}$ hexoses (mainly glucan) remained in the solid fraction (90-95\%), and only 1.5-4.0\% were solubilised (Fig. 4A). Further degradation of hexoses was not significant. In the case of pentoses (mainly xylan) only $15-20 \%$ of the initial amount remained in the solid fraction. Only $36-48 \%$ of the xylan was transferred into the liquid fraction, and the amount of the further-degraded or not-determined material was rather high, $36-42 \%$. Similar mass balances have been achieved for other lignocellulosic materials (corn stover, salix, spruce) [3]. The lowest amount of further-degraded/not-determined compounds and the highest solubilisation of pentoses were obtained with pretreatment at $210{ }^{\circ} \mathrm{C}$ for $5 \mathrm{~min}$. For SPHS, similar trends were observed concerning the recovery after pretreatment (Fig. 4B). Hexoses remained in the solid fraction (86-96\%), and only a minor part was solubilised (5-7\%) or further degraded (0-10\%). A minor part of the initial xylan 
(10-18\%) from SPHS remained in the solid fraction, while $20-75 \%$ was solubilised, and a large amount (26-60\%) was further degraded or not determined. The reason for the high amount of these compounds for pretreatment at $190{ }^{\circ} \mathrm{C}$ is probably that this was the least severe condition which has led to poor pretreatment and rather heterogenous material. The samples taken for analysis could have been non-representative and add an error for mass balance calculation. In this comparison it should be kept in mind that only stems were used from dry hemp while hemp silage contained both stems and leaves.

Fig. 5 shows the mass balances both in the pretreatment and the enzymatic hydrolysis for the different experimental setups. The fractions are represented as percentage of the initial dry raw material and are defined as: i) the waterinsoluble fraction (mainly lignin), which can be further utilised as solid fuel; ii) glucan remained in the solid residue after hydrolysis; iii) glucan solubilised during the enzymatic hydrolysis; iv) sugars solubilised in the steam pretreatment; and v) volatile and further degraded compounds, which were not accounted for. The goal of the experiments was to maximise yield of solubilised glucose in the enzymatic hydrolysis of the steam pretreated material (grey part of the bars in the figure).

In the case of dry hemp (Fig. 5 and Table 5) the maximal glucose yields were similar for pretreatment at $210{ }^{\circ} \mathrm{C}$ and $215{ }^{\circ} \mathrm{C}$ with $\mathrm{SO}_{2}$ impregnation (373 and $383 \mathrm{~g} \mathrm{~kg}^{-1}$, respectively), but there was a significant difference in the amount of solubilised hemicellulose sugars (249 and $199 \mathrm{~g} \mathrm{~kg}^{-1}$ ). Both pretreatment conditions were found to be efficient for improving cellulose hydrolysis, but the lower temperature resulted in less inhibitor formation. As the process economy is strongly affected by the utilisation of the hemicellulose fraction [31], pretreatment at $210{ }^{\circ} \mathrm{C}$ for $5 \mathrm{~min}$ after $\mathrm{SO}_{2}$ impregnation was found to be the best condition for hemp stem. The optimal pretreatment condition (210/5 min/2\% SO2) for hemp and hemp silage is similar to pretreatment conditions obtained for agricultural lignocellulosics $\left(200{ }^{\circ} \mathrm{C} / 10 \mathrm{~min} / 2 \%\right.$ $\mathrm{SO}_{2}$ for corn stover [16], $190{ }^{\circ} \mathrm{C} / 10 \mathrm{~min} / 0.2 \% \mathrm{H}_{2} \mathrm{SO}_{4}$ for wheat straw [5]; or for woods $\left(210{ }^{\circ} \mathrm{C} / 5 \mathrm{~min} / 2.5 \% \mathrm{SO}_{2}\right.$ for softwood [32], $205^{\circ} \mathrm{C} / 4 \mathrm{~min} / 2 \% \mathrm{SO}_{2}$ for hardwood [33].

For hemp silage (Fig. 5 and Table 5), the highest glucose yield $\left(372 \mathrm{~g} \mathrm{~kg}^{-1}\right)$ was obtained by pretreatment at $210^{\circ} \mathrm{C}$ for 5 min with $\mathrm{SO}_{2}$ impregnation, followed by the pretreatment at $200{ }^{\circ} \mathrm{C}$ with $\mathrm{SO}_{2}$ impregnation $\left(342 \mathrm{~g} \mathrm{~kg}^{-1}\right)$. The highest yield of sugars solubilised during the pretreatment was also obtained in the case of $210^{\circ} \mathrm{C}$ with $\mathrm{SO}_{2}$ impregnation, therefore this was chosen as the best pretreatment condition. Thus, based on glucose yields in enzymatic hydrolysis, steam pretreatment at $210{ }^{\circ} \mathrm{C}$ for $5 \mathrm{~min}$ with $\mathrm{SO}_{2}$ impregnation was chosen as the optimal pretreatment conditions both for dry hemp and hemp silage.

\subsection{Results of SSF of the whole slurry and of the separated fibre}

SSF of SPH and SPHS was performed using either the whole slurry or the separated solid fraction of the materials pretreated using the selected optimal pretreatment conditions: $2 \% \mathrm{SO}_{2}$ impregnation followed by $210{ }^{\circ} \mathrm{C} / 5 \mathrm{~min}$ treatment. Fig. 6 shows the glucose, xylose and ethanol concentrations during the $72 \mathrm{~h}$ of the SSF. Decrease of xylose concentration is an indicator for microbial contamination of the fermentation, as S. cerevisiae can only consume C6 sugars. Neither decrease of xylose concentration nor lactic acid production (data not shown) was observed during the SSF experiments. With SPH, the separated fibre resulted in a slightly higher ethanol concentration compared to the whole slurry (Fig. 6A). Final ethanol concentrations in the case of whole slurry and the separated fibre were determined to $18.4 \mathrm{~g} \mathrm{l}^{-1}$ and $21.3 \mathrm{~g} \mathrm{l}^{-1}$,

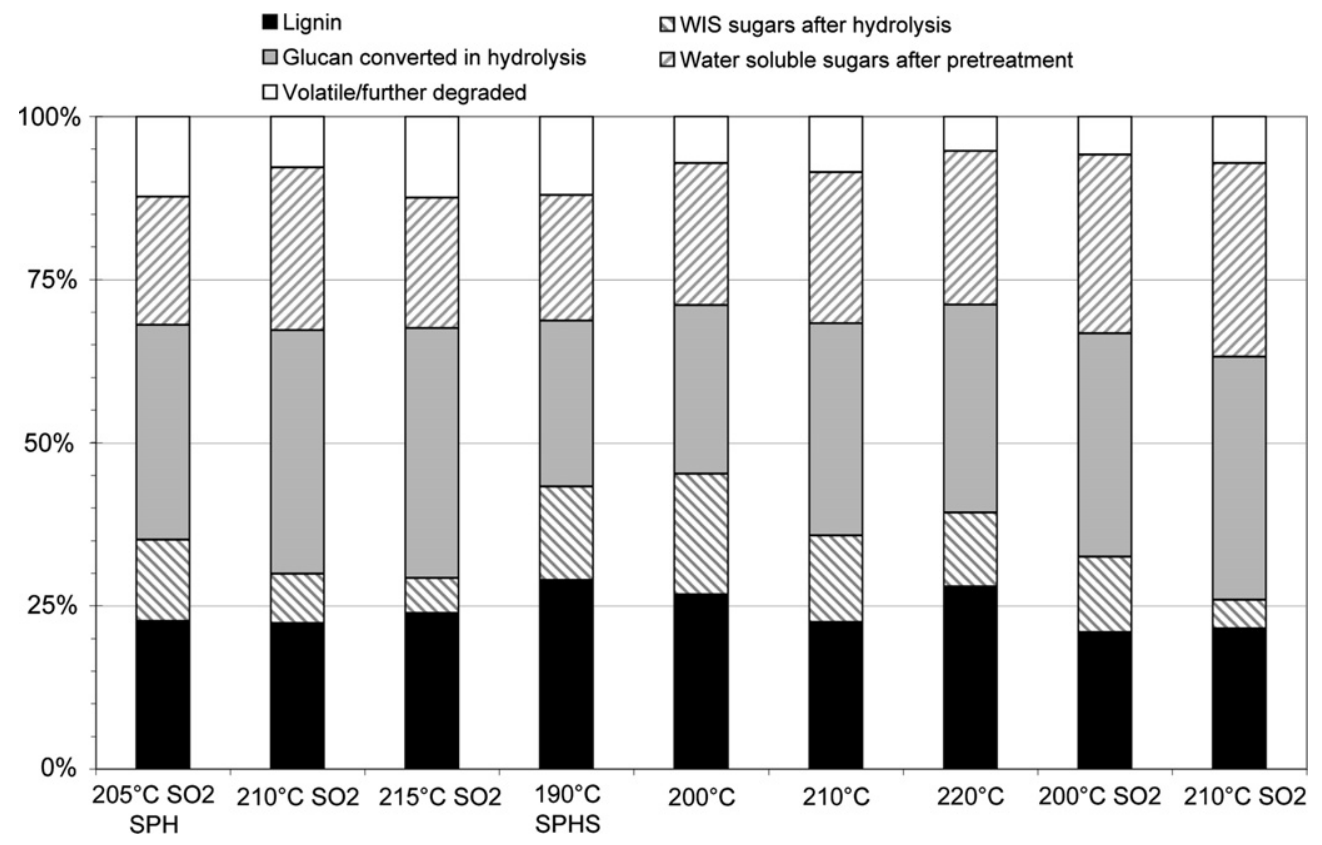

Fig. 5 - Lignin and carbohydrate fractions after steam pretreatment and enzymatic hydrolysis of dry hemp (SPH) and hemp silage (SPHS), as percentage of the dry weight of raw material. 

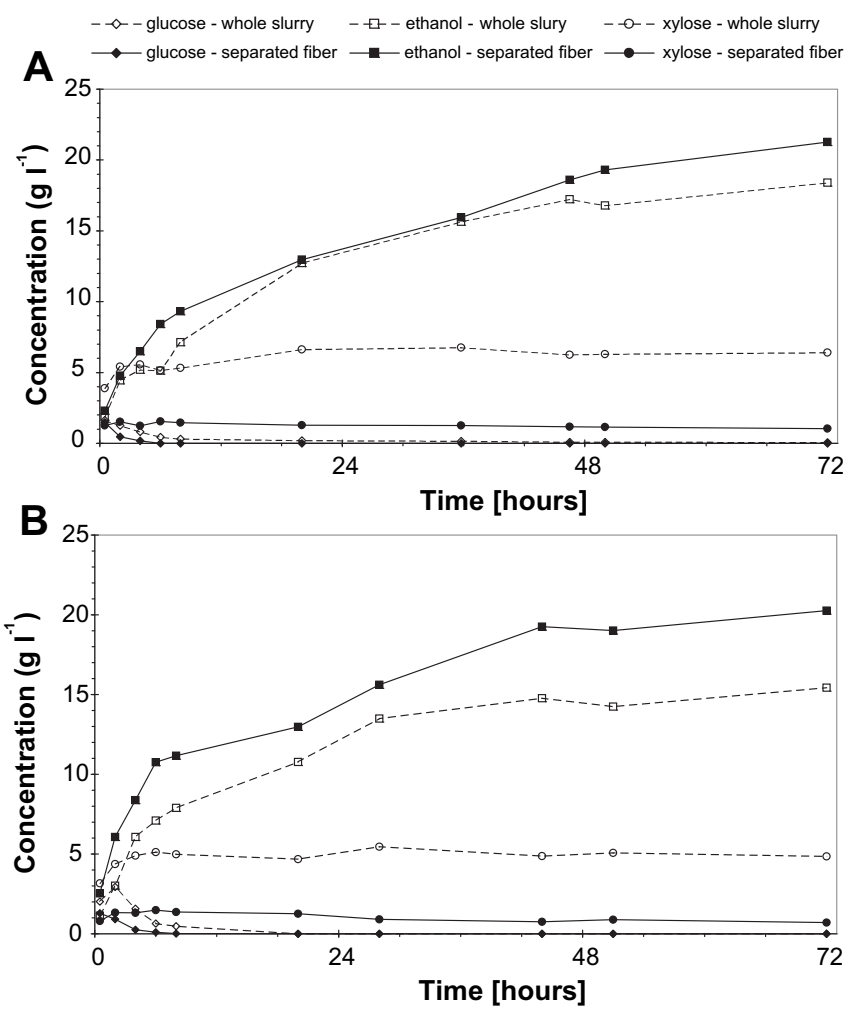

Fig. 6 - Concentrations of glucose, xylose and ethanol in SSF of SPH (A) and SPHS (B). Substrates were pretreated at $210{ }^{\circ} \mathrm{C}$ for $5 \mathrm{~min}$ using $2 \% \mathrm{SO}_{2}$ impregnation (open symbols and dashed lines - whole slurry, closed symbols and continuous lines- separated fibre).

respectively. This corresponds to a total process yield of 148 and $171 \mathrm{~g} \mathrm{~kg}^{-1}$ ethanol based on raw dry hemp DM, respectively. The overall ethanol yields were $62.4 \%$ and $74.1 \%$ of the theoretical maximum based on the glucan content in the raw material.

With SPHS, the difference between the performance of the whole slurry and the separated fibre was more pronounced (Fig. 6B). The final ethanol concentrations were 15.4 and $20.3 \mathrm{~g} \mathrm{l}^{-1}$, respectively. The total ethanol yields were 125 and $163 \mathrm{~g} \mathrm{~kg}^{-1}$ based on hemp silage DM, respectively, corresponding to $53.4 \%$ and $71.2 \%$ of the theoretical. The significant difference might be caused by the inhibitory effect of the organic acids present in the whole slurry [28,29]. At the beginning of the fermentation of the whole slurry, $6.0 \mathrm{~g} \mathrm{l}^{-1}$ lactic acid and $6.8 \mathrm{~g} \mathrm{l}^{-1}$ acetic acid were present and the concentrations of these compounds were constant during the process. The presence of acetic acid is rather important, as its $\mathrm{pK}_{\mathrm{a}}$ value is rather close to the $\mathrm{pH}$ of the SSF. The inhibitory effect of the organic acids is connected with the protonated form; because it can diffuse across the plasma membrane [28] (36\% of the acetic acid and $7 \%$ of the lactic acid is in protonated form at $\mathrm{pH}$ 5). The concentration of protonated acetic acid was calculated to be $40.8 \mathrm{mmol}^{-1}$.

Maize silage has previously been tested for ethanol production in SSF [34]. The yield for wet-oxidised (WO) maize silage was found to be $83 \%$ (of the theoretical maximum), which corresponds to $308 \mathrm{~g} \mathrm{~kg}^{-1}$ ethanol based on DM WO maize silage ( $82 \%$ of the theoretical maximum), which is slightly less than what has been found for WO corn stover [35]. It should be noted, that during WO, beside hemicellulose, a part of the lignin also degrades, which results in a pretreated material rich in cellulose. In the case of wheat straw, $132 \mathrm{~g} \mathrm{~kg}^{-1}$ ethanol based on dry wheat straw SSF yield was achieved [5], while in case of Salix, $201 \mathrm{~g} \mathrm{~kg}^{-1}$ ethanol based on dry wood yield was achieved, and the ethanol yield in SSF was higher compared to the theoretical maximum than in the present study [36].

The results obtained both with SPH and SPHS show that separation of fibre and liquid fraction prior to SSF is advantageous. In the case of SPHS, the effect was more pronounced compared to SPH. Separation is beneficial not only because of the removal of inhibitory compounds with the liquid fraction, but also a new fraction arises containing mainly C5 sugars (mono- and oligomers) some C6 sugars and other organic compounds like acetic acid, furfural and HMF, which can be utilised separately, e.g., for biogas production.

\section{Conclusions}

Steam pretreatment with an $\mathrm{SO}_{2}$ catalyst was shown to be an efficient pretreatment method prior to ethanol production from both dry hemp and hemp silage. In both cases impregnation with $2 \% \mathrm{SO}_{2}$ followed by steam pretreatment at $210^{\circ} \mathrm{C}$ for $5 \mathrm{~min}$ were found to be the most suitable pretreatment conditions within the investigated intervals. No significant effect of the ensiling process was detected at the optimal conditions for conversion of hemp to ethanol. In further experiments, utilisation of the liquid fraction and SSF residue for biogas production to increase the energy recovery will be investigated.

\section{Acknowledgements}

The Environmental Fund of Region Scania, the Hungarian National Research Fund (OTKA - K 72710) and The Swedish Research Council for Environment, Agricultural Sciences and Spatial Planning are kindly acknowledged for their financial support. Enzymes were kindly donated by Novozymes A/S (Bagsværd, Denmark). Thanks to Thomas Prade at the Swedish University of Agricultural Sciences for providing dry hemp.

\section{R E F E R E N C E S}

[1] Sun Y, Cheng J. Hydrolysis of lignocellulosic materials for ethanol production. Bioresour Technol 2002;83:1-11.

[2] Tengborg C, Galbe M, Zacchi G. Influence of enzyme loading and physical parameters on the enzymatic hydrolysis of steam-pretreated softwood. Biotechnol Progr 2001;17:110-7.

[3] Sassner P, Galbe M, Zacchi G. Techno-economic evaluation of bioethanol production from three different lignocellulosic materials. Biomass Bioenerg 2008;32:422-30.

[4] Öhgren K, Rudolf A, Galbe M, Zacchi G. Fuel ethanol production from steam-pretreated corn stover using SSF at higher dry matter content. Biomass Bioenerg 2006;30:863-9. 
[5] Linde M, Jakobsson E-L, Galbe M, Zacchi G. Steam pretreatment of dilute $\mathrm{H}_{2} \mathrm{SO}_{4}$-impregnated wheat straw and SSF with low yeast and enzyme loadings for bioethanol production. Biomass Bioenerg 2008;32:326-32.

[6] Martın C, Galbe M, Wahlbom CF, Hahn-Hägerdal B, Jönsson LJ. Ethanol production from enzymatic hydrolysates of sugarcane bagasse using recombinant xylose-utilising Saccharomyces cerevisiae. Enzym Microb Technol 2002;31: 274-82.

[7] Sipos B, Réczey J, Somorai Z, Kádár Z, Dienes D, Réczey K. Sweet sorghum as feedstock for ethanol production: enzymatic hydrolysis of steam-pretreated bagasse. Appl Biochem Biotechnol 2008;153:151-62.

[8] Szijártó N, Kádár Z, Varga E, Thomsen AB, Costa-Ferreira M, Réczey K. Pretreatment of reed by wet oxidation and subsequent utilization of the pretreated fibers for ethanol production. Appl Biochem Biotechnol 2009;155:83-93.

[9] Keshwani DR, Cheng JJ. Switchgrass for bioethanol and other value-added applications: a review. Bioresour Technol 2009; 100:1515-23.

[10] Struik PC, Amaducci S, Bullard MJ, Stutterheim NC, Venturi G, Cromack HTH. Agronomy of fibre hemp (Cannabis sativa L.) in Europe. Ind Crops Prod 2000;11:107-18.

[11] Harris AT, Riddlestone S, Bell Z, Hartwell PR. Towards zero emission pulp and paper production: the BioRegional MiniMill. J Clean Prod 2008;16:1971-9.

[12] Sgriccia N, Hawley MC, Misra M. Characterization of natural fiber surfaces and natural fiber composites. Compos Part A 2008;39:1632-7.

[13] Kymälaäinen H-R, Sjöberg A-M. Flax and hemp fibers as raw materials for thermal insulations. Build Environ 2008;43: 1261-9.

[14] Rice B. Hemp as a feedstock for biomass-to-energy conversion. J Ind Hemp 2008;13:145-55.

[15] Keller A, Leupin M, Mediavilla V, Wintermantel E. Influence of the growth stage of industrial hemp on chemical and physical properties of the fibres. Ind Crops Prod 2001;13:35-48.

[16] Öhgren K, Galbe M, Zacchi G. Optimization of steam pretreatment of $\mathrm{SO}_{2}$ impregnated corn stover for fuel ethanol production. Appl Biochem Biotechnol 2005; 121-124:1055-68.

[17] Garcia-Jaldon C, Dupeyre D, Vignon MR. Fibers from semiretted hemp bundles by steam explosion treatment. Biomass Bioenerg 1998;14:251-60.

[18] Nykter M, Kymäläinen H-R, Thomsen AB, Lilholt $H$, Koponen $\mathrm{H}$, Sjöberg A-M, et al. Effects of thermal and enzymatic treatments and harvesting time on the microbial quality and chemical composition of fibre hemp (Cannabis sativa L.). Biomass Bioenerg 2008;32:392-9.

[19] Shin S-J, Sung YJ. Improving enzymatic hydrolysis of industrial hemp (Cannabis sativa L.) by electron beam irradiation. Radiat Phys Chem 2008;77:1034-8.

[20] Ghose TK. Measurement of cellulase activities. Pure Appl Chem 1987;59(2):257-68.

[21] Berghem LER, Pettersson G. The mechanism of enzymatic cellulose degradation. Eur J Biochem 1974;46:295-305.
[22] Palmqvist E, Hahn-Hägerdal B, Galbe M, Larsson S, Stenberg K, Szengyel Z, et al. Design and operation of a bench-scale process development unit for the production of ethanol from lignocellulosics. Bioresour Technol 1996;58: 171-9.

[23] Taherzadeh MJ, Liden G, Gustafsson L, Niklasson C. The effects of pantothenate deficiency and acetate addition on anaerobic batch fermentation of glucose by Saccharomyces cerevisiae. Appl Microbiol Biotechnol 1996;46: 176-82.

[24] Rudolf A, Alkasrawi M, Zacchi G, Liden G. A comparison of batch and fed-batch simultaneous saccharification and fermentation of steam pretreated spruce. Enzym Microb Technol 2005;37:195-204.

[25] Sluiter A, Ruiz R, Scarlata C, Sluiter J, Templeton D. Determination of extractives in biomass laboratory analytical procedure. NREL Report No. TP-510-42619; 2008.

[26] Sluiter A, Hames B, Ruiz R, Scarlata C, Sluiter J, Templeton D, et al. Determination of structural carbohydrates and lignin in biomass, laboratory analytical procedure, NREL Report No. TP-510-42618; 2008.

[27] Sluiter A, Hames B, Ruiz R, Scarlata C, Sluiter J, Templeton D. Determination of sugars, byproducts, and degradation products in liquid fraction process samples, laboratory analytical procedure, NREL Report No. TP-510-42623; 2008.

[28] Palmqvist E, Hahn-Hägerdal B. Fermentation of lignocellulosic hydrolysates. II: inhibitors and mechanisms of inhibition. Bioresour Technol 2000;74:25-33.

[29] Larsson S, Palmqvist E, Hahn-Hägerdal B, Tengborg C, Stenberg K, Zacchi G, et al. The generation of fermentation inhibitors during dilute acid hydrolysis of softwood. Enz Microb Technol 1999;24:151-9.

[30] McDonald P, Henderson AR, Ralton I. Energy changes during ensilage. J Sci Fd Agric 1973;24:827-34.

[31] von Silvers M, Zacchi G. A techno-economical comparison of three processes for the production of ethanol from pine. Bioresour Technol 1995;51:43-52.

[32] Stenberg K, Trenborg C, Galbe M, Zacchi G. Optimization of steam pretreatment of $\mathrm{SO}_{2}$ impregnated mixed softwoods for ethanol production. J Chem Technol Biotechnol 1998;71: 299-308.

[33] Sassner P, Galbe M, Zacchi G. Steam pretreatment of Salix with and without SO2 impregnation for production of bioethanol. Appl Biochem Biotechnol 2005;121-124:1101-18.

[34] Oleskowicz-Popiel P, Lisiecki P, Holm-Nielsen JB, Thomsen $\mathrm{AB}$, Thomsen $\mathrm{MH}$. Ethanol production from maize silage as lignocellulosic biomass in anaerobically digested and wet-oxidized manure. Bioresour Technol 2008;99: 5327-34.

[35] Varga E, Klinke HB, Réczey K, Thomsen AB. High solid simultaneous saccharification and fermentation of wet oxidized corn stover to ethanol. Biotechnol Bioeng 2004;88: 567-74.

[36] Sassner P, Mårtensson C-G, Galbe M, Zacchi G. Steam pretreatment of $\mathrm{H}_{2} \mathrm{SO}_{4}$-impregnated Salix for the production of bioethanol. Bioresour Technol 2008;99:137-45. 